\title{
Capital Account Regulation and National Autonomy: The Political Economy of the New Welfare Economics
}

\author{
Luiza Peruffo* \\ Pedro Perfeito da Silva** \\ André Moreira Cunha***
}

\begin{abstract}
The 2007-2009 Global Financial Crisis (GFC) eroded the consensus around the benefits of capital mobility within mainstream economics. Against this background, this paper discusses to what extent the new mainstream position on capital flow management measures, based on the New Welfare Economics, expands the policy space of developing and emerging economies (DEEs). This paper argues that the new position can be classified as an embedded neoliberal one, given that it keeps liberalization as its ultimate goal, while nonetheless accepting to mitigate some of its harmful consequences. After comparing the capital account policies of China and Brazil, this paper concludes that the policy prescriptions of the New Welfare Economics do not lead to higher levels of national autonomy for DEEs and are likewise unable to curb financial instability in these countries.
\end{abstract}

Keywords: capital mobility; capital controls; New Welfare Economics; Political Economy; embedded neoliberalism.

\section{Introduction}

The International Monetary and Financial System (IMFS) evolves around the tension between the internationalization of economic relations pushed by markets and the pursuit of national autonomy by states (Block 1980; Eichengreen 2019; Eichengreen, Mehl and Chitu 2019; Ocampo 2017; Polanyi 2001). After the Second World War, the Bretton Woods

\footnotetext{
Federal University of Rio Grande do Sul (UFRGS), Porto Alegre-RS, Brazil; luiza.peruffo@ufrgs.br. ORCID iD 0000-0002-5744-4804.

** Central European University (CEU), Budapest, Hungary; perfeito_pedro@phd.ceu.edu. ORCID iD 00000002-2469-0996.

*** Federal University of Rio Grande do Sul (UFRGS), Porto Alegre-RS, Brazil; andre.cunha@ufrgs.br. ORCID iD 0000-0002-3746-5974.
} 
System (BWS) leaned to the second pole of this tension, granting space for governments to pursue full employment policies and limit the pressure of global financial markets over national exchange rates (Davidson 2017; Eichengreen 2019; Skidelsky 2009). That trend was reversed during the escalation process that led to the collapse of the BWS, when national autonomy was increasingly constrained by the internationalization of economic relations, notably of global capital (Kirshner 2003; Strange 1998). This process continued somewhat uninterrupted until the 2007-2009 Global Financial Crisis (GFC) took place, which did not represent an inflexion point in favour of states, but instead, created the environment to limit the freedom of markets in some respects (Baker 2018; Gallagher 2014).

At all times, the developments of economic theory have translated these tensions between states and markets in the IMFS by way of policy prescriptions. The immediate postwar period, for instance, marked an inflection in economic theory and practice in terms of the role the state should play in the economy, as stirred by the work of John Maynard Keynes $(1924,1930)$. As the balance of power tipped towards markets, however, new economic models gave the basis for policies in which the role of states was reduced. This is important because, in monetary and financial affairs, mainstream ideas define which policies are acceptable, and which ones are not (Kirshner 2003).

The regulation of cross-border finance is representative of this dynamic among, namely, (1) the tensions in the IMFS, (2) the developments in economic theory, and (3) the resulting policy prescriptions. Under the cognitive authority of the International Monetary Fund (IMF) (Moschella 2012), mainstream policy prescriptions on capital controls have changed substantially over time. Capital controls evolved from being widely accepted during the BWS to being highly discouraged following its collapse. More recently, the GFC created the context to change again conventional wisdom on cross-border financial policy. Since then, certain capital controls have been reincluded - under the new term 'capital flow management measures' - as a legitimate component of the macroeconomic policy toolkit as a means to curb financial instability, while financial liberalization was maintained as the ultimate policy goal (Chwieroth 2014; Gallagher 2015; IMF 2012; Ocampo 2017; Ostry, Ghosh and Korinek 2012).

In light of this background, this paper investigates to what extent the new mainstream position on capital account regulation affects the policy space of developing and emerging economies (DEEs). Despite widespread pressure from mainstream economic theory for cross-border financial deregulation since the end of the BWS (Fisher 1998: 2, 8), DEEs have pursued different approaches on capital controls. While some of them have used capital controls as part of a broader development strategy to maintain a competitive exchange rate and attract certain types of flows, other DEEs have focused on financial stability, attempting to 'play by the same rules as the core countries', as summarized by Jeanne, Subramanian and Williamson (2012: 2). Building on Structuralist and Post-Keynesian theories, this paper explains the former strategy not only as a consequence of greater policy space, but also as a cause: the capacity of an economy to implement capital controls as part of its development strategy is related to its initial position in centre-periphery dynamics and to how it engages with the financial globalization process. 
This theoretical argument is illustrated with China and Brazil's capital controls policies, examples of economies that broadly align with a long-term development strategy and with a short-term financial stability approach. Although China's superior economic performance to Brazil's cannot be solely attributed to contrasting capital controls policies, we argue that these countries' policy options are a symptom of their respective positions in the IMFS' hierarchy. As a matter of fact, China can deviate from standard policies more easily than Brazil, because it faces a lower external constraint due to its production structure and international financial integration profile, which contribute to render China as less peripheral than the latter. Brazil, in contrast, features a typical peripheral DEE. Its dependence on foreign resources translate into a higher incentive for it to play by mainstream's rules, which in turn contributes to reinforce its vulnerable position.

This paper makes two contributions to the literature. Firstly, by drawing on the theoretical frameworks developed by Cerny (2008), Ban (2016) and Bohle and Greskovits (2012, 2019), it explains the new mainstream position on capital controls in light of the concept of embedded neoliberalism, which combines the self-regulating market principle with the mitigation of some of its harmful social consequences. Such political economy regime differs from the embedded liberalism that characterized the BWS and allowed countries to restrict economic liberalization as a mean to pursue their domestic objectives (Blyth 2002; Helleiner 2019; Ruggie 1982; Sandbrook 2011). Conversely, the new prescription accepts capital controls up until the point where they do not harm the broader process of economic liberalization, thus limiting national autonomy, especially for DEEs. Secondly, it contributes to the understanding of how DEEs have been dealing with the challenges imposed by capital mobility. The contrasting experiences of China and Brazil with capital control policies are a case that serves to differentiate DEEs among themselves. Whereas state power has been in general diminished by market power, it seems that some states have been more successful in preserving their national autonomy than others. ${ }^{1}$

This paper is divided in six sections. Following this introduction, the second section reviews the dynamics among states and markets in the IMFS, focusing on how the result of these dynamics resulted in different policy prescriptions on capital controls throughout time. The third section builds on Structuralist and post-Keynesian theories to discuss the role of capital controls for the national autonomy of DEEs. The fourth section presents the experiences of China and Brazil with capital control policies. The fifth section compares the two cases, outlining the analytical implications of these two countries for other DEEs. The sixth section concludes the paper, suggesting that the policy prescriptions of the New Welfare Economics do not lead to higher levels of national autonomy for DEEs and are likewise unable to curb financial instability in these countries.

\section{Institutional Change Theory and capital account regulation: from the gold standard to the Global Financial Crisis}

According to Polanyi (2001), the capitalist economy is characterized by the tension between the self-regulating market principle and the social need for embeddedness. In this 
approach, the expansion of the self-regulating market principle leads to deep social dislocations, motivating the mobilization of different social segments (Sandbrook 2011). Such reactions forge what Polanyi (2001) defines as the double movement: the use of the state to protect society from the expansion of the market realm and its negative effects. The generalization of the Polanyian double movement, put forward by Blyth (2002), leads to a theory of institutional change in which the political and economic institutions develop following a pendular movement, determined by the permanent conflict between the social segments that demand the regulation of the market and those that are impaired by such intervention.

In this perspective, the expansion of the self-regulating market mobilizes the dislocated social segments around alternative ideas, demanding countervailing economic and social policies. In periods of economic crisis, such counter-movements are able to implement these ideas, fostering institutional changes that increase the degree of economic interventionism. The same process occurs when the state's regulation expands over markets. As markets are impaired by interventionism, market actors also conceive ideas to promote liberalizing institutional changes, taking advantage from periods of economic instability to implement them.

This theory of institutional change is useful to understand the evolution of capital control policies over time. In a nutshell, capital controls help to loosen the linkages between the policies designed to meet domestic objectives (such as income and employment) and the effect these policies might have in terms of the economy's external equilibrium (reflected in its balance of payments and in its international investment position). To that extent, capital controls can be regarded as part of the macroeconomic toolkit that allows the state to minimize the negative effects of free markets over society. In the specific case of capital markets, these negative effects are mostly associated with financial crises as well as with an excessive volatility of important macroeconomic prices, such as the exchange and interest rates. The acceptance of the use of capital controls as a legitimate policy tool, however, has fluctuated throughout history, along with Polanyi's pendulum.

In theory, an economy that wants to keep its monetary autonomy needs to give up either its exchange rate stability or restrain its capital mobility - what is known as the impossible trinity' or Mundell-Fleming trilemma. Nevertheless, certain rules of the international system are set by global powers, whose preferences spill over to the rest of the world. Anchored on free trade and capital movement at the expense of monetary autonomy, the Gold Standard was the touchstone of the British economic hegemony in the nineteenth century (Eichengreen 2019, Chapter 2; Levitt 2006: 168; Ruggie 1982). During the Gold Standard, imposing capital controls to limit the expansion of the haute finance would cost countries the exclusion from Britain's trade and financial relations, which was hardly in the interest of domestic elites worldwide, who in general opted to be part of the global arrangement. Subsequently, the transition from the British to the American hegemony gave rise to a new set of interests, moving Polanyi's pendulum away from the self-regulating market towards a greater role for the state, which was embodied in the BWS (Eichengreen 2019, Chapter 4). Then, American objectives of locking a coalition with Western Europe 
and restoring global trade could only be achieved if governments worldwide were able to pursue full employment policies (Block 1980). As a result, the BWS was based on the principle of embedded liberalism, whereby states could limit capital movement in order to pursue domestic objectives (Blyth 2002; Eichengreen 2019; Helleiner 2019; Ruggie 1982; Sandbrook 2011). Similar to Britain's hegemony, the access to America's trade and financial networks was conditional to joining the BWS, an option that was followed by most policymakers across the globe.

To that extent, capital mobility can be regarded as a structural feature of the international system (Eichengreen 2019). As put forward by Andrews (1994: 202), 'the degree of [capital] mobility systematically alters state calculations and behaviour [...] [it is] a constraining condition which rewards certain behaviours and punishes others.' Put differently, the use of capital control policies has been both rewarded and punished, depending on how the tension between states and markets was translated into policy prescriptions at different times.

Since the establishment of the BWS, the International Monetary Fund (IMF) has been the guardian of policies that govern capital mobility (Moschella 2012). At its origins, its recommendations echoed the then conventional wisdom founded on Keynesian economics (Davidson 2017; Minsky 1993), prescribing capital controls as a way to contain an inherently unstable financial system. However, the particular environment that was at the origins of the BWS gradually faded away and the global economic order witnessed the emergence of neoliberalism (Helleiner 1995; Kirshner 2003; Levitt 2006; Strange 1998). Then, the IMF adjusted its policy prescriptions on capital controls accordingly (see for example Fisher 1998), eventually replacing exchange rate stability by capital account liberalization as the main conditionality to offer financial assistance to DEEs facing macroeconomic difficulties (Chwieroth 2010; Moschella 2012). This went exactly in the opposite direction of the IMF's original mandate.

The IMF's 'new' institutional view on capital controls put forth in the aftermath of the GFC serves to illustrate the IMF's role in expressing the tension between the self-regulating market principle and the social need for embeddedness. The severe effect of the GFC on centre economies created a new set of class-based interests and international alliances that contrasted with the previous equilibrium. ${ }^{2}$ If in the 1990 s the IMF explained the financial crises in DEEs by blaming these countries' domestic institutional flaws and urging them to remove capital controls (Fisher 1998: 3; Prasad et al 2003: 6), it changed its view when developed countries became the epicentre of the crisis (Baker 2018; Helleiner 2010). The GFC weakened the Neoclassical argument that the effects of capital mobility were a function of the institutions adopted by each country, not least because now it was harming the global (financial) elite, which pressured for tighter regulation.

The post-GFC has put a halt to Polanyi's pendulum swing towards freer markets. This process has been consubstantiated in the emergence of the New Welfare Economics (NWE) and corresponding policy prescriptions. The NWE was built upon neoclassical assumptions and, to that extent, it does not represent a movement away from the self-regulating market principle. If anything, the NWE serves to limit free market expansion before 
it forges a reaction towards a greater role for the state. The NWE approach acknowledges the existence of market failures in free markets and argues these risks can be mitigated by regulation and institutional design (Korinek 2018; Ostry, Ghosh and Korinek 2012; Stiglitz 2019; Tobin 2000).

The conciliation between the globalization project and a partial reform of the IMFS can be explained as a case of embedded neoliberalism. According to Ban (2016), Cerny (2008) and Bohle and Greskovits $(2012,2019)$, embedded neoliberalism conforms with the self-regulating market principle while recognizing that free markets lead to massive social dislocation and disruptive socio-political conflicts. The adoption of the NWE approach implies keeping economic liberalization as a long-run objective, while slowing down its pace and/or mitigating some of its harmful consequences (Korinek 2018; Ostry, Ghosh and Korinek 2012; Ghosh, Ostry and Qureshi 2018).

The NWE's embedded neoliberalism is reflected in the IMF's new institutional position, which now admits the use of certain capital controls as part of the legitimate policy toolkit (IMF 2011, 2012, 2016). Still, the IMF advises that capital controls should be adopted only as a last resort, keeping financial integration and capital account liberalization as an ultimate policy goal. According to Chwieroth (2014), the IMF's new institutional position offered a compromise solution, cementing a reformist coalition that generated partial gains for heterogeneous agents. One the one hand, DEEs' bureaucracies and worldwide exporters gained a legitimate path to regulate capital flows and prevent exchange rate overvaluation. Accepting these marginal advances came at the opportunity cost of using the post-GFC context to foster a deeper global monetary governance reform. On the other hand, advocates of neoliberal free market principles, such as financial institutions, independent central bankers and the IMF staff in general, accepted the rebirth of capital controls as a legitimate policy, as they gained the opportunity to frame the new regulations at the convenience of the globalization project. ${ }^{3}$

Explaining the new mainstream position on capital account regulation as embedded neoliberal is useful to understand why it does not contribute to change the fundamental peripheral condition of DEEs in the IMFS. As the next section will discuss, DEEs face certain predicaments in the IMFS that are simultaneously both a cause, as well as a consequence, of their peripheral position in the global system.

\section{The role of capital controls to DEEs' national autonomy}

The notion of 'national autonomy' is invoked by political scientists and economists alike to refer to 'the ability of a nation-state as a collectivity to make decisions which shape its political and economic future,' as summarized by Peter B. Evans (1971: 676). Back in the 1950s and the 1960s, Structuralist scholars warned that this ability could be curtailed by the way states are integrated into the global system. According to these traditions, the world is divided between a dominant, autonomous core and a dependent periphery due to fundamental economic and political domestic characteristics. This divide explains the role each economy plays in global production structures that simultaneously link and 
reinforce the 'North' and 'South' division (Prebisch 1949; Furtado 1974). Since the 1970s, International Political Economy (IPE) researchers have also argued that national autonomy was increasingly threatened by the power of markets and free capital (See, for example, Andrews 1994 and Strange 1998). The globalization phenomenon, as put forward by Kirshner (2009: 41), 'affects state capacity and autonomy, and thus reshapes the relative power of the state vis-à-vis non-state actors, social forces and market pressures', besides reshuffling the 'relative distribution of capabilities and vulnerabilities between states' (See also Levitt 2006: 168-175). This section brings together centre-periphery and state versus markets structural dimensions to explain the role of capital controls in the DEEs' national autonomy.

Founded on the ideational underpinnings of neoliberalism, the period that went from the post-Bretton Woods until the GFC was marked by an incessant pressure from developed countries, led by the United States, for DEEs to liberalize their capital accounts (Ocampo 2017: 110). According to the conventional wisdom at the time, capital account liberalization should be pursued not only because it was 'an inevitable step on the path of development,' as the then First Deputy Managing Director of the IMF Stanley Fischer (1998: 2) reasoned. It should also be pursued given the potential benefits of liberalization in terms of economic growth and welfare outweighing its costs. In fact, under this perspective, financial liberalization costs would be mostly associated with the poor macroeconomic management of countries, their fragile banking systems and with domestic political instability (Fischer 1998: 3; Prasad et al 2003: 8). If governments behaved well, markets would reward their good policies in a virtuous cycle of economic growth and development. If governments misbehaved, markets would discipline them, which would also contribute to development eventually. Either way, it was up to countries individually to reap the benefits of capital account liberalization, framed as a natural stage of development.

The DEEs reaction to such pressure varied widely, which can be explained by taking into account both structural factors of the IMFS underlying hierarchy and political economy elements specific to each country. On the one hand, DEEs that were more dependent on foreign capital were less able to resist the adoption of the 'best (neoliberal) practices' advocated by developed, creditor states (Armijo and Katada 2014: 49). On the other, DEEs integration to the globalization process was also explained by the preferences of their domestic elites and subjacent economic motives. ${ }^{4}$ The financialization process that accompanied the rise of globalization and neoliberalism was reflected in greater financial elites power worldwide (Epstein 2005). For weaker peripherical states, however, it was easier to shape policies to their benefit, even if those neoliberal, free market policies came at the expense of a lower wellbeing of the domestic collectivity (Levitt 2006: 173-174). By this token, the starting point of DEEs in centre-periphery dynamics, and of their domestic political economy, matters in that it provides an understanding of why some DEEs have managed to remain more autonomous than others since the world economy has grown closer. 
DEEs that gave in to the pressure emanated from neoliberal theory, developed countries and their own financial elites soon felt the destabilizing effects of free capital markets over their liberalized capital accounts. The financial crises that would follow in the late 1990s triggered a reaction of Latin American and East Asian DEEs that was characterized by the creation of mechanisms of monetary and financial cooperation designed to reduce their dependence on multilateral institutions, dominated by developed countries, their rules and their currencies (Armijo and Katada 2014: 54-55). Individually, DEEs adopted international reserve accumulation strategies as a basic defence structure against an unstable IMFS, a strategy that was not only very costly but also inconsistent with mainstream economic theory on open macroeconomics, according to which flexible exchange rates should not require (massive) reserve accumulation.

While the explanation for the stockpiles of international reserves accumulated by DEEs since the early 2000s can be associated with mercantilist and self-insurance motives, there is also a link thereof with the practical impossibility of these countries to adopt capital controls as a legitimate economic policy tool under the neoliberalism paradigm. As Kirshner (2003: 12) masterly grasped, 'with regard to money, the power of ideas does more than just shape the possible. It defines the feasible' (also see Andrews 1994). As discussed in section 2, giving up free capital mobility is not entirely under governmental control inasmuch as it can be regarded as a structural feature of the IMFS (Andrews 1994; Rey 2015). ${ }^{5}$ In any case, theoretically, the adoption of a floating exchange rate regime would still enable monetary policy independence in a financially integrated world. The issue for DEEs is that their currencies and the assets denominated in their currencies occupy the position of risky assets in financial markets portfolios, which is reflected in a procyclical and volatile demand that is transmitted to exchange rate movements (Andrade and Prates 2013; Kaltenbrunner 2018; Kaltenbrunner and Painceira 2015, 2018; Paula, Fritz and Prates 2017; Prates and Paula 2017; for an IPE perspective on the currency hierarchy, see Cohen 2015, 2018). In this context, the accumulation of international reserves serves to limit the exchange rate flexibility, either through direct intervention of the monetary authority or simply due to a gigantic volume of international reserves boosts creditors' confidence on the DEEs' economic health. As put forward by Ilzetzki, Reinhart and Rogoff (2017: 7), 'to some extent, reserves have replaced capital controls.' In order to be certain, under capital market liberalization, the accumulation of international reserves can be seen as a way to circumvent the marginal place occupied by DEEs' currencies and assets in global financial dynamics and to preserve some of their monetary policy independence, which can be regarded as an important aspect of a country's national autonomy.

Therefore, international reserve accumulation can be linked to the DEEs' intrinsic lower level of national autonomy in an IMFS where national currencies perform the role of international currencies. As there is not a truly international currency - as the bancor, proposed by Keynes -, domestic currencies compete among themselves to fulfill the functions of medium of exchange, unit of account and reserve of value at the international level (Cohen 2015: 8-10). The capacity of currencies to stand out in this international competition is intrinsically related with the political and economic power of its issuing state 
(Cohen 2015: 10-15). It is possible to say that centre-periphery dynamics are transmitted to the monetary domain, in which currencies issued by developed countries will be placed higher in the monetary hierarchy than those issued by DEEs (Ocampo 2001; Paula, Fritz and Prates 2017; Prates and Paula 2017).

The post-Bretton Woods IMFS - characterized by the fiduciary dollar standard, floating exchange rates and almost free capital mobility, has increased the dollar dominance and exacerbated the negative consequences of the monetary hierarchy for DEEs (Fritz and Prates 2018; Gallagher et al 2014; Ocampo 2017; Paula, Fritz and Prates 2017). If on the one hand the United States enjoys an enormous macroeconomic flexibility - the socalled exorbitant privilege -, delaying and deflecting the cost of its domestic and external adjustment onto the rest of the world (Cohen 2015: 22), on the other, DEEs are 'expected to behave in ways that generate 'credibility' to financial markets, which means that they are expected to adopt pro-cyclical (austerity) policies during crisis,' as remarked by Ocampo (2001: 11).

The existence of a high level of international reserves inspires confidence in financial markets because creditors know they will have access to hard currency when they decide to move their investments elsewhere. This dynamic between the ability of the United States to offer the safest and most liquid assets of the IMFS and the huge demand of DEEs for those assets as a way to preserve some of their national autonomy for monetary policymaking is, by and large, rooted in the use of national currencies beyond their monetary domain (Cohen 2018: 27; Gourinchas, Rey and Sauzet 2019; Vermeiren and Dierckx 2012: 1658-1659).

All in all, in a context where capital flows can easily punish or reward governments for policy decisions (Andrews 1994; Kirshner 2003), DEEs are compromised between opting for opening up their capital account to attract the much needed foreign capital and regulating cross-border flows to create certain policy space. The use of capital controls does not denote that a country will 'cut itself off from the international capital markets', as Fisher (1998: 10) once claimed by putting forth a competing argument for capital account liberalization. Instead, capital controls policies serve to circumvent the negative consequences of the monetary hierarchy under free capital mobility, partially delinking 'the effects of capital flows on interest and exchange rates and, therefore, reducing the tradeoff that authorities face between monetary policy autonomy and exchange rate stability', as noted by Ocampo (2017: 132). To that extent, these policies simultaneously attenuate external financial instability and increase the policy space for counter-cyclical macroeconomic policies, including long term policies for economic development (Ocampo 2017: 128; on how national monetary policies are constrained by the global financial cycle, see also Gourinchas, Rey and Sauzet 2019; Obstfeld 2015; Rey 2015).

While capital controls can reduce financial volatility and create policy space at the theoretical level, the use of such policy space to implement a long-term development strategy in practice is a more complicated matter. The same policy instrument can be deployed for different reasons. Simply implementing capital control policies does not signify that the government is using them as a means to create policy space; it might simply be managing a 
circumstantial financial instability problem. Using capital controls as a development strategy means that they are being calibrated alongside a broader macroeconomic toolkit to reach development goals - including (but not limited to) industrial, credit, education, and social policies. Identifying the consistency of capital controls as development policies is not a straightforward task, but a closer look into the cases of China and Brazil serves to contrast how different approaches to capital controls can, over the long run, contribute to different levels of national autonomy.

\section{China and Brazil: two tales of capital controls}

By delving into the cases of China and Brazil, this section argues that the DEEs capacity to use capital controls as part of a broader development strategy depends not only on their initial position in the centre-periphery dynamics, but also on how their governments choose to engage with the financial globalization process. China and Brazil are examples of how international and domestic dimensions can interact to engender higher or lower levels of national autonomy, respectively, in a dollar-centred system with nearly free capital mobility.

\section{From shield to sword: financial statecraft in China $^{6}$}

China's integration with the global economy began with market-oriented reforms inaugurated in 1978 but remained weak until the early 1990s. Capital flows were minimal due to strict capital controls and due to China's low appeal for international investors as a socialist economy with limited exposure to global trade (Prasad and Wei 2007: 421). Asian economies represented the largest share of China's inflows, which was constituted mainly by foreign direct investment (FDI) - a type of flow that tends to be more stable and associated with other benefits, such as technological transfers (Prasad et al 2003: 10; Prasad and Wei 2007: 429; Prasad 2016, chapter 3). While China's external debt rose from 3\% of the GDP in 1982 to $14 \%$ of the GDP in 1990, it remained significantly below DEEs' average, with little sovereign borrowing and private companies being discouraged from taking on external debt. China's external debt remained stable, accounting for around $15 \%$ of the GDP between 1990 and 1998, whereas external debt averaged 50\% of the GDP in Latin America and just above that in Southeast Asian countries such as Thailand, Philippines and Indonesia, whereas India's external debt accounted for some 25\% of its GDP (Prasad and Wei 2007: 433-435). In parallel, the government started to conduct a slow process of opening its financial system in the early 1980s, allowing a few foreign banks and insurance companies to undertake business in certain cities, and committed to a greater liberalization of its financial services to foreign participants as it became a member of the World Trade Organization (WTO) in December 2001 (Helleiner and Wang 2019: 224; Yongding 2009: 2-6). Yet, as of 2020, China's financial system is largely closed to foreign banks. In 2016 , the participation of foreign banks accounted for only $1.2 \%$ of the total banking assets in China (Helleiner and Wang 2019: 224). 
While a gradual capital account liberalization began to take place in 1994, China escaped from the financial turbulences that affected financially integrated DEEs in the late 1990s (Gallagher et al 2014: 2-3; Yongding 2009: 1). Thereafter, China removed most restrictions for FDI inflows and relaxed controls over portfolio investments, albeit maintaining quota schemes as well as controlling money market transactions and financial derivatives (Gallagher et al 2014: 3). The fact that China's net capital inflows were large in magnitude yet small in relation to the size of its economy (Prasad and Wei 2007: 425) meant that swings in the 'international market sentiment' caused limited domestic disturbances. China was also quite detached from Western pressure, since by 2003 , the United States and the European Union economies together accounted for only 15\% of China's FDI inflows (Prasad and Wei 2007: 429). In moments of higher uncertainty, such as during the Asian crisis in 1997-98 and of economic slowdown in advanced economies, such as the period following the dot-com crisis in 2001, FDI flows to China remained essentially unchanged, despite having decreased in most DEEs (Prasad and Wei 2007: 425).

Chinese policies of leaving the financial issue under state control and preventing international banks from penetrating the domestic system serve to demonstrate China's financial nationalism (Helleiner and Wang 2019; Prasad 2016, Chapter 1; Vermeiren and Dierckx 2012). Overall, Chinese regulations of capital inflows and outflows have been subordinated to a broader project to direct credit toward strategic development goals (Gallagher et al 2014: 2), rather than being a concession to Western advanced economies (Vermeiren and Dierckx 2012: 1651). China's development project has been connected with a nationalist desire of resisting to American financial hegemony, which encompassed securing its monetary sovereignty and independence from foreign financial institutions (Helleiner and Wang: 225). Cultivating the renminbi (RMB) as an alternative to the US dollar was a natural corollary to these ambitions (Cohen 2014, 2018; Vermeiren and Dierckx 2012: 1659-1660).

Gradually, and more explicitly, since the GFC, China replaced its inward and defensive financial nationalism to an outward orientation in which the RMB internationalization plays a key role (Helleiner and Wang 2019: 225). In July 2005, China announced the move away from a fixed exchange rate against the US dollar to a more flexible arrangement (Yongding 2009: 28-29). From July 2005 to July 2015, the RMB's real effective exchange rate appreciated by $58 \%$ ( $44 \%$ nominal), while the appreciation against the dollar was $26 \%$ (Das 2019: 8). That was accompanied by policies that partially liberalized China's foreign exchange markets, such as the establishment of markets for currency forwards and swaps, and the expansion of market participants (Das 2019: 7).

As China increases its global ambitions, it faces a trade-off between internationalizing the RMB and cautiously opening its capital account (Prasad 2016, Chapter 6; Vermeiren and Dierckx 2012: 1660-1661). The appeal to frame the RMB as an international currency requires a certain financial liberalization in China so that foreigners can buy and sell at will, in addition to having the right to issue debt and equities denominated in RMBs (Cohen 2014: 48-49). In 2010, an offshore RMB market was established in Hong Kong 
SAR that was soon replicated in other countries (Das 2019: 15; Vermeiren and Dierckx 2012: 1660).

In addition, before having the RMB included in the IMF's Special Drawing Right (SDR) basket, China undertook a number of financial market liberalization measures, loosening interest rate controls and opening its domestic bond market to foreign central banks and sovereign wealth funds (Das 2019: 15). China's integration into global financial markets was shortly reflected in greater foreign exchange pressures against the RMB. For instance, an announcement made in August 2015 that the People's Bank of China (PBoC) would increase RMB flexibility triggered a surge in global financial market volatility and outflows from China as market participants anticipated the depreciation of the RMB. China responded with strong foreign exchange intervention (selling US\$ 321 billions of reserves in the second half of 2015) and capital controls enforcement to limit outflows (Das 2019: 10-11). In any case, as China engaged deeper with the globalization order, it soon began to feel the destabilizing effects of free capital markets, effects which have long been known by DEEs like Brazil.

\section{Brazil's old and new external vulnerabilities?}

External constraints have historically played a major role in defining domestic economic policies in Brazil. For Brazil, the US ascent as the global monetary power was ambivalent. On the one hand, adjusting Brazilian economic policies to follow Washington's prescriptions meant that Brazil could benefit from the United States' direct aid and indirect support through the Bretton Woods Institutions. In addition, maintaining a good relationship with the United States in general also worked as a quality stamp to attract the much needed international private capital. Conversely, these policies often came at the cost of subordinating domestic objectives to external ones. From deciding on its exchange rate regime to appointing economic officials that pleased US authorities, Brazilian governments have explicitly and implicitly weighted the pros and cons of challenging the United States' preferences concerning its chosen domestic policy decisions (see for example Armijo 1993: 264; Loureiro 2014). The tensions from Brazil's asymmetrical relationship with the United States have been transmitted to Brazilian domestic politics, in which opposing political groups perceive the alignment with the US as an advantage or as a disadvantage to overcome underdevelopment. To that extent, Brazil's domestic debate on economic development and national autonomy has been fundamentally associated with Brazil's position in the IMFS' hierarchy.

In contrast with China's financial closeness, the Brazilian government enthusiastically engaged with the expansion of international financial markets in the late 1960s (Goldfajn and Minella 2007: 361-362). The upsurge in the international credit supply prompted by US expansionary policies at the time allowed countries like Brazil, which previously had no regular access to financial markets, to become large-scale borrowers (Batista 1987: 11). In the 1960s and 1970s, Brazil's capital account convertibility enabled the authorization of profit remittances to FDI, loans and other forms of finance. The expansion of the external 
debt during the 1970s was contained by the reversal of market conditions at the end of that decade, as the Mexican moratorium interrupted voluntary capital flows to Brazil, triggering an external debt crisis in 1982 - a problem settled only in 1994 with the issuance of the Brady bonds (Goldfajn and Minella 2007: 353-357). During this period, the external problem mainly took over the domestic agenda: Brazil tightened its monetary and fiscal policies and followed the guidance set by the IMF for most of the time, with the intent to generate enough hard currency to pay its external obligations.

The 1990s were a turning point for Brazil's engagement with the globalization order and its neoliberal policy prescriptions (Goldfajn and Minella 2007: 370; Souza and Carvalho 2011). Following an initial opening in the late-1980s, when Brazil started to liberalize capital inflows, in the 1990s, the government committed with capital account openness, liberalizing capital outflows, removing restrictions over FDI, and allowing foreign institutional investors to acquire derivatives and domestic firms' equities (Goldfajn and Minella 2007: 372). In parallel, Brazil' financial system went through a deep process of restructuring, which began in the aftermath of its currency stabilization program in 1994, the Real Plan. The system in place until 1994 had a strong presence of public banks, a restricted number of foreign banks, a major role for directed credit, narrow competition, and a substantial reliance of banks' profits on revenues correlated with high inflation. The financial system that emerged in the new low inflation environment had a much larger presence of foreign banks and a reduced share of public banks, a combination that resulted in a freer allocation of credit. All in all, Brazil became much more open financially by the late 1990s. This partially explains why the Brazilian Central Bank was unable to contain the speculative attack against the Brazilian currency in January 1999, which precipitated a fundamental change in Brazil's macroeconomic policy framework, that of changing from a fixed to a floating exchange rate regime.

From then on, subsequent Brazilian governments put in place several policies to increase the resilience of the Brazilian economy against financial instability which, nonetheless, by ignoring Brazil's place as a peripheral country in the IMFS, ended up replacing old vulnerabilities for new external ones (Kaltenbrunner and Painceira 2015, 2018). However, since the international economy entered into a buoyant phase in the early 2000s, with rising commodity prices (fuelled by China's global integration) and high international liquidity, these new external vulnerabilities would not be clearly exposed until 2011, when the commodity bonanza period had ended. Brazilian authorities seized the prosperous period to build up international reserves and to reduce the dollar-denominated debt, including by paying off Brazil's debt with the IMF two years ahead of schedule. While dealing with the traditional constraints of foreign currency shortages and of high levels of public indebtedness in foreign currency, Brazilian governments lowered controls for foreign participants to operate in Brazil (Prates and Paula 2017; Souza and Carvalho 2011). Gradually, foreign participants accounted for a large share of domestic assets, rendering Brazil's external vulnerability increasingly denominated in domestic currency. The greater participation of foreign players has been transmitted to higher foreign exchange market 
pressures, reducing the capacity of Brazilian policymakers to pursue domestic objectives without subordinating them to the external balance.

\section{DEEs' national autonomy in light of China's and Brazil's capital control policies}

The contrasting experiences of China and Brazil with international financial integration and capital control policies serve to shed light on the more general case of DEEs' national autonomy in a world of increasing capital mobility. As a matter of fact, while there is a structural component in international monetary and financial relations that compromises DEEs' national autonomy, DEEs have some degree of agency in determining the profile of their integration into global financial markets. Focusing the comparative analysis on the 1990s onwards, China has maintained a high level of capital controls, while Brazil started off from an already lower level to decrease even further in the early 2000s up to the GFC (see Figure 1 below).

Figure 1 - Capital Controls Index, 1995-2015

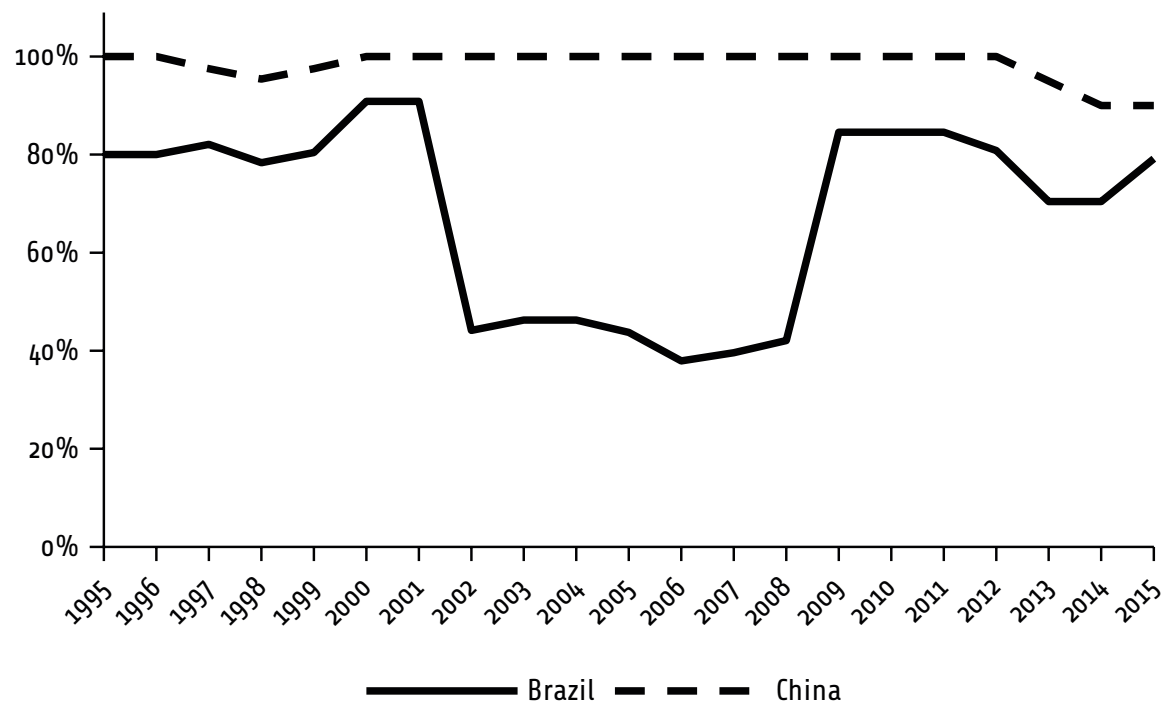

Source: Created by the authors based on Fernandez et al (2016)

Note: This reformulated version of the CCI took into consideration the average level of capital controls over four types of flows: direct investments, portfolio investments, other investments, and derivatives.

In addition to different levels of capital controls, China and Brazil have also diverged with regard to the type of the regulatory instruments they employ to restrict capital mobility. For one, Brazil has removed most of administrative controls, narrowing down the restrictions to cyclically adjusted tax-based regulations over more volatile transactions such as portfolio flows, debt and derivatives (Fritz and Prates 2018). As these controls target short-term flows, Alami (2019) and Kaltenbrunner and Painceira (2018) argue that Brazilian authorities have mostly aimed to safeguard financial stability rather than 
restricting capital mobility. China, in turn, despite having gradually loosened capital controls, has kept a variety of regulatory instruments, including taxes, quota schemes and administrative prohibitions (Gallagher et al 2014; Prasad and Wei 2007). While intention is very hard to establish, the articulation between the different regulations can be seen as a subordination of capital mobility to China's national development strategy (Helleiner and Wang 2019), which contrasts with Brazil's arguable focus on financial stability.

Notwithstanding the differences between Chinese and Brazilian approaches to capital controls, both countries have increased their financial integration from 1991 to 2015 (see Figure 2 below), evoking the structural feature of capital mobility in the IMFS. Under the surface of this apparent convergence, however, China and Brazil developed different relationships with financial globalization, which can be at least in part traced back to their capital controls policies. Brazilian foreign liabilities, for instance, are composed mostly by portfolio and debt flows, whereas Chinese foreign liabilities constitute mostly direct investments (see Figure 3 below). One may argue that this means Brazil is more exposed to short-term changes in the global financial cycle than China - a DEE that enjoys a longer commitment by foreign capital.

Figure 2 - Financial Integration Index, 1991-2015

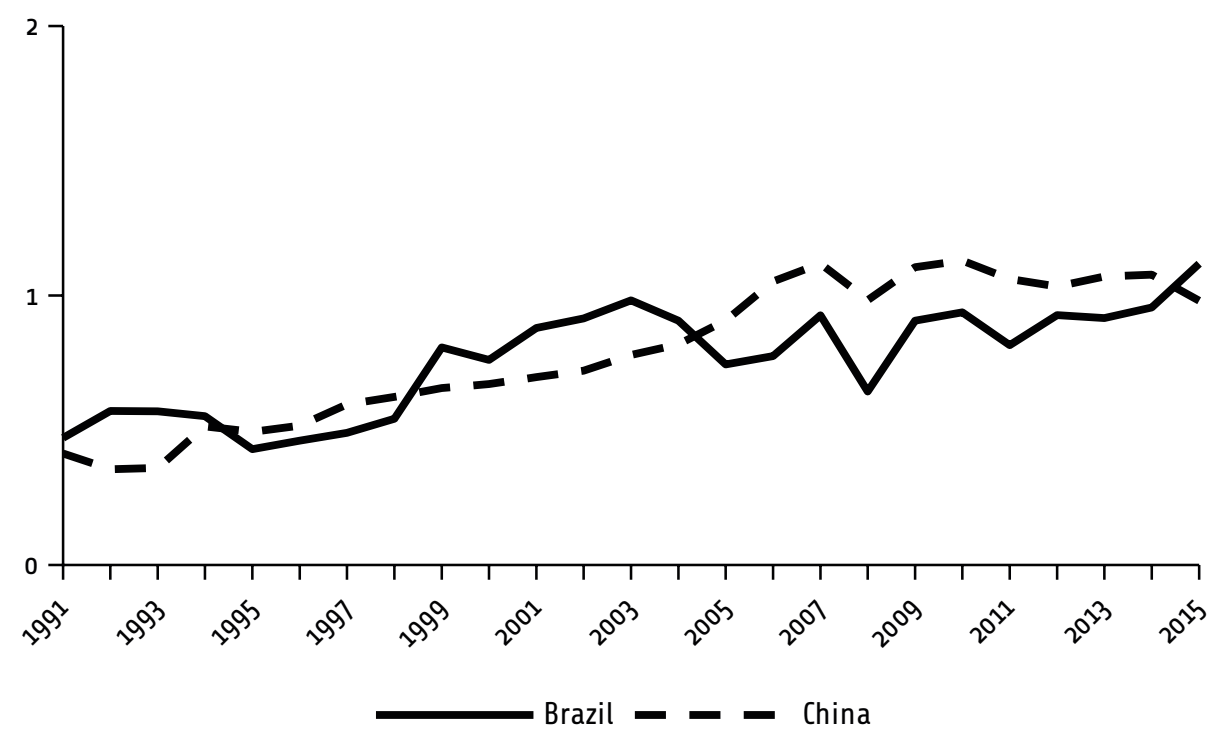

Source: Created by the authors based on Lane and Milesi-Ferretti (2018).

Note: The FII is calculated through the sum of foreign assets and liabilities, divided by the GDP.

China and Brazil opposite distributions between foreign assets and liabilities (see Figure 4 below) serve to illustrate how the capacity of a country to employ capital controls as part of a broader development strategy can be seen not only as a consequence of greater policy space, but also as a cause thereof. From a Structuralist perspective, the broad 'North' and 'South' division may be considered as a creditor and debtor division. At first, both China and Brazil were dependent on foreign capital. Due to a set of factors, including 
(but not limited to) political economy domestic issues, Brazil 'played by the rules' and accepted an integration led by liabilities (from the late 1960s on), while China remained largely closed and targeted specific kinds of foreign capitals.

Figure 3 - Composition of Foreign Liabilities, 1991-2015

(A) Brazil

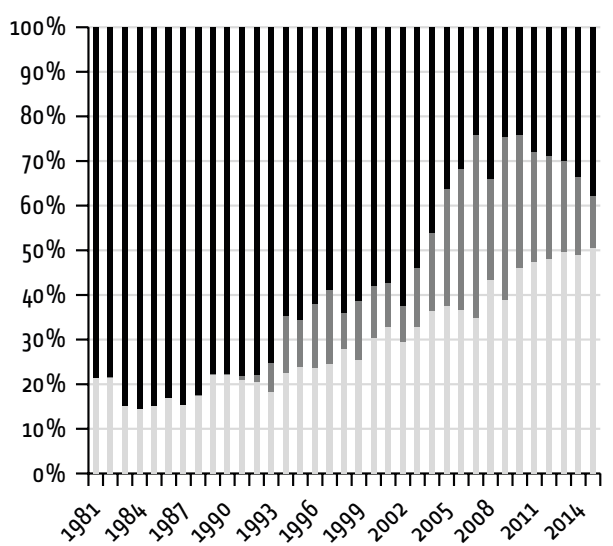

(B) China

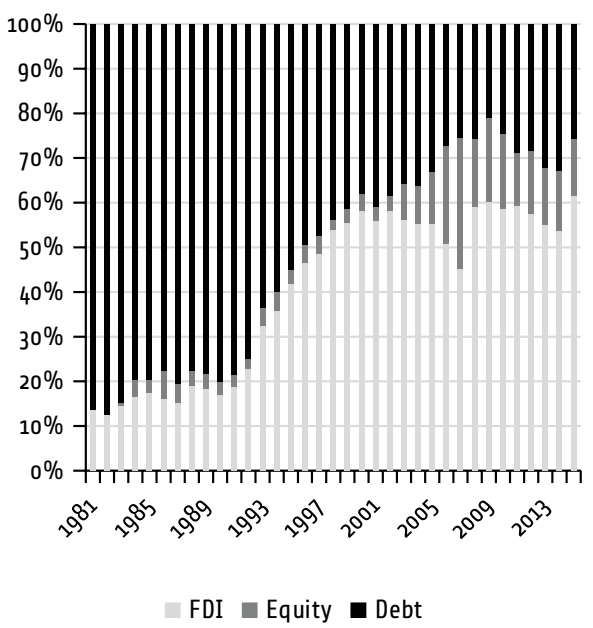

Source: Adapted by the authors from Lane and Milesi-Ferretti (2018).

Figure 4 - Composition of Foreign Stocks, 1991-2015

(A) Brazil

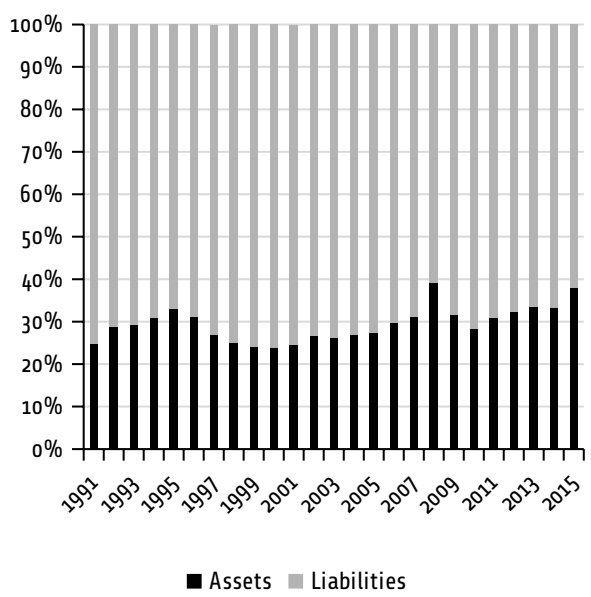

(B) China

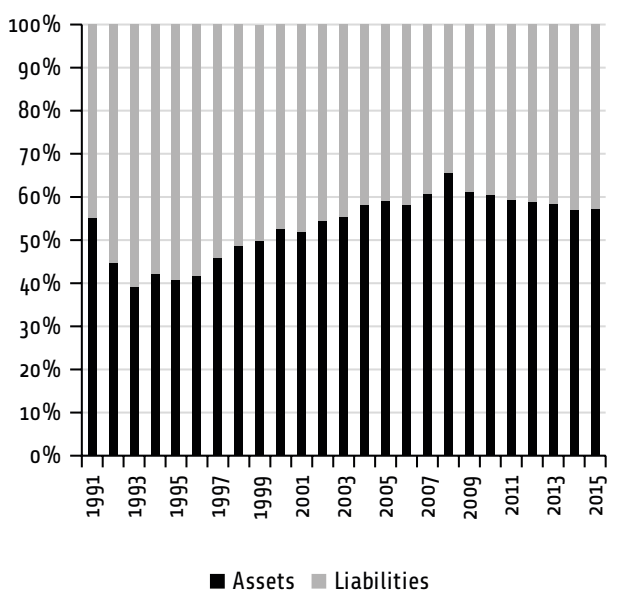

Source: Adapted by the authors from Lane and Milesi-Ferretti (2018).

Over the years, Brazil's more passive, dependent engagement to financial globalization engendered a cumulative process in which short-term inflows led to currency 
overvaluation, pressuring the current account balance and enduring the predominance of liabilities over assets. In the long run, currency overvaluation harmed exports' competitiveness and, consequently, the current account balance, increasing the demand for capital inflows. In addition, a financial integration led by liabilities, by definition, pressures the current account due to the income payments to non-residents. In light of these developments, China's capital controls policies served as part of a set of policies that allowed it to break with this vicious circle and ultimately increase its national autonomy. This assumption is in line with the arguments in favour of capital controls put forward by authors such as Fritz and Prates 2018; Gallagher 2015; Grabel 2017; Kregel 2004; Ocampo 2017; Prates and Paula 2018; Souza and Carvalho 2011.

Taken together, China's and Brazil's distributions and compositions of foreign assets can be linked with the issue of national autonomy. For China, the preponderance of foreign assets implies a higher degree of national autonomy and, increasingly, a projection of its monetary and financial power abroad (Cohen 2018). In the case of Brazil, the prevalence of foreign liabilities implies a lower level of national autonomy, since the country's external balance is more dependent on the expectations of global investors. This is illustrated, for instance, by the greater volatility of the Brazilian real to the global financial cycle in comparison to the Chinese renminbi (see Figure 5 below).

Figure 5 - Real Effective Exchange Rate and Global Financial Cycle, 1991-2015

(A) Brazil

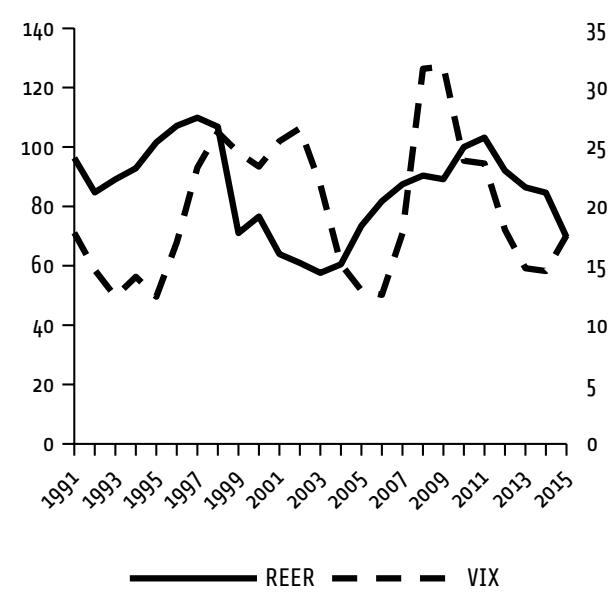

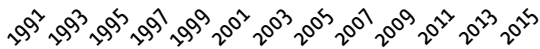

(B) China

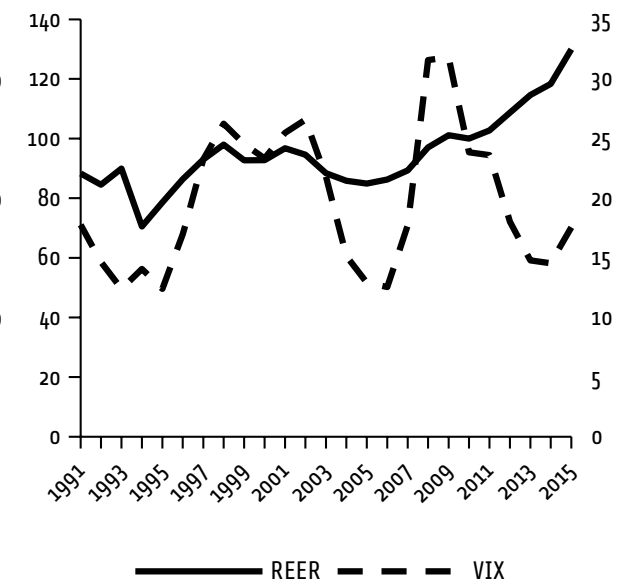

Source: Adapted by the authors from The World Bank (n.d.) and Chicago Board Options Exchange (n.d.). Note: In the empirical literature, the CBOE Volatility Index (VIX) is an efficient proxy for the global financial cycle (Rey 2015). Lower VIX levels are associated with an expansion of the global financial cycle, while higher VIX levels indicate the reverse.

Finally, the relationship between the exchange rate and the global financial cycle also serves to reveal the relevance of capital flows to explain the current account balance, which can be regarded as an important element of the DEEs national autonomy. Overall, there is a link between a stable and undervalued exchange rate and a consistent current account surplus (see Figure 6 below) that reduces DEEs dependency for foreign currency. 
As demonstrated by the Chinese experience, capital controls contributed to maintain an undervalued exchange rate, which in turn contributed to China's current account surpluses. In contrast, the focus of Brazilian capital control policies on financial stability was conversely ineffective in terms of insulating its currency from the global financial cycle, a result that was reflected in a correspondingly erratic current account balance, at least until 2020. In other words, Brazil has left to the market the determination of one of the most important macroeconomic prices: the exchange rate.

Figure 6 - Real Effective Exchange Rate and Current Account Balance, 1991-2015
(A) Brazil
(B) China

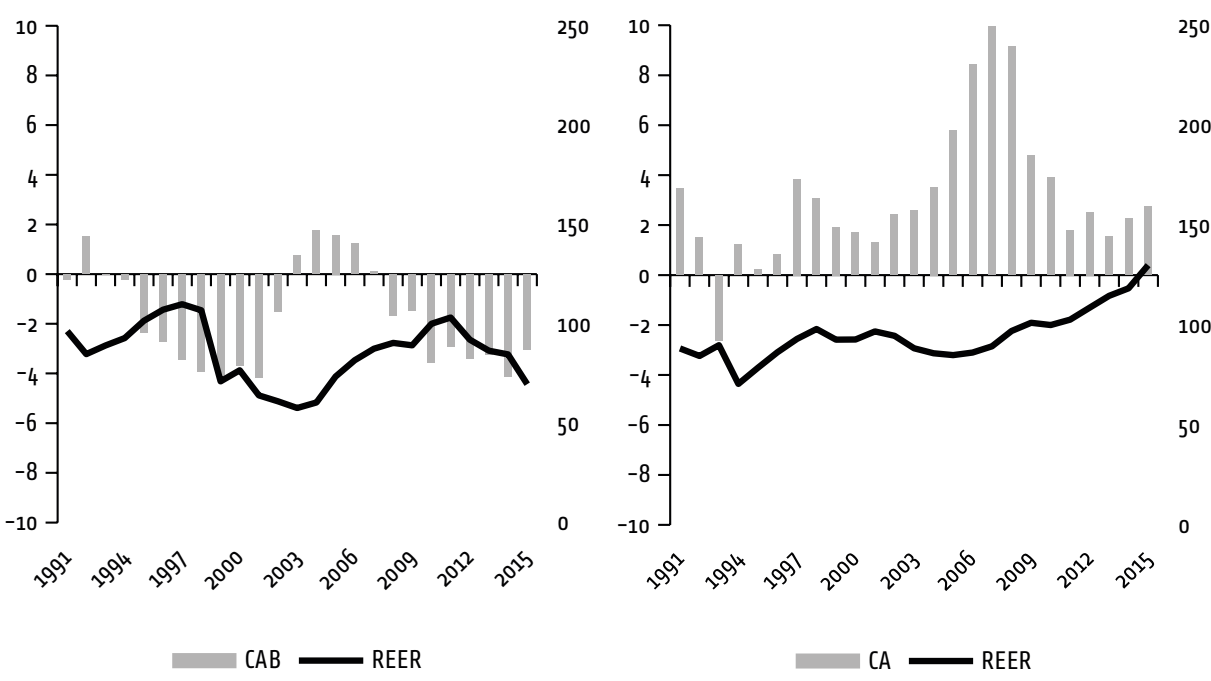

Source: Created by the authors based on The World Bank (2020).

\section{Final remarks}

This paper discussed how the new mainstream position on capital account regulation affects the national autonomy of DEEs. It explained the NWE's view on capital controls as a case of embedded neoliberalism, given that it accepts to mitigate financial instability while capital account liberalization remains an ultimate policy goal. It argued that capital mobility should be understood as a structural feature of the IMFS that, in turn, reproduces centre and periphery dynamics in monetary and financial relations in the absence of a truly international currency. This hierarchical understanding of the IMFS supported the argument of why DEEs become more vulnerable in an almost free capital mobility world and why capital controls should be a permanent component of their macroeconomic toolkit. Since the NWE's does not support that conclusion, this paper argued that the policy prescriptions drawn from the NWE do not imply in a higher level of national autonomy in the case of DEEs. 
This theoretical argument was illustrated with the experiences of China and Brazil. This paper argued that, while DEEs start off from an unprivileged position in the international system - including in its monetary and financial spheres -, they hold some degree of agency in deciding how to engage with the financial globalization process. Overall, China has subordinated its capital controls policies to its national development project, while Brazil has enjoyed the pros and cons of being a financially more open economy, targeting its capital controls to deal with the financial instability issue. The comparative analysis conducted hereby served to shed light on the long-term results engendered by each specific strategy. Brazil's external balance sheet is largely subject to the vulnerability to the global financial cycle, increasing the external constraint to reach its domestic policy objectives. China's foreign stocks, in contrast, are more autonomous from external variables, meaning that it faces a lower external constraint to pursue its domestic policy objectives. Even so, the greater volatility that China has been facing in response to its gradual financial opening is a reminder of the inherent instability of the current IMFS and of the place reserved for DEEs within that system.

\section{Notes}

1 Andrews (1994: 212-213) has highlighted this point in the context of Germany and other members of the European Monetary System.

2 To an extent, the GFC catalysed a tension that was already in place before the Lehman Brothers went bankrupt in September 2008. Authors such as Levitt (2006: 170) somewhat anticipated the new equilibrium that would unfold after the GFC, most specifically, that 'The globalization project requires a peaceful and stable international political order [...] the continued liberalization of international economic relations is problematic.'

3 In contrast to the New Welfare Economics, the Post-Keynesian tradition proposes a deep reform of the IMFS based on the Keynes Plan, encompassing cross-border financial regulations for both capital exporters and importers, sharing the cost of the external adjustment between surplus and deficit countries and reducing the dollar dominance (Akyüz 2017; Davidson 2017).

4 The interplays between politics and financial policy is by no means an exclusive feature of DEEs. Dagher (2018), for instance, has extensively analysed the symbiotic relationship among politicians, financiers, bankers and large companies to explain procyclical financial regulation by revisiting the context of ten financial crises, nine of which in the context of advanced economies (see, in particular, pages 52-57). On the role played by policy elites in decision-making, see Cohen (2018: 9). On the specific case of Chinese elites, see Vermeiren and Dierckx (2012). On the case of Brazil, see, for instance, Armijo (1993: 270-271).

5 Andrews (1994) notes that capital mobility can be understood as the outcome not only of policy decisions, but also of changes in the world's technological capacity and in the private sector's practice. In his words, 'changes in the market itself, however, as well as in the technological capabilities of market actors, have jointly reduced the impediments to capital movements between states quite independently of the regulatory decisions of governments' (Andrews 1994: 199).

6 This section's title is inspired by a study by Armijo and Katada (2014: 46-47) on the use of financial statecraft by rising powers.

$7 \quad$ This section's title is inspired by a study by Kaltenbrunner and Painceira (2015, 2018) on Brazil's subordinated integration into a financialised and hierarchical SMFI. 


\section{References}

Akyüz, Y. 2017. Playing with Fire: Deepened Financial Integration and Changing Vulnerabilities of the Global South. New York: Oxford University Press.

Alami, I. 2019. 'Post-crisis Capital Controls in Developing and Emerging Countries: regaining Policy Space? An historical materialist engagement.' Review of Radical Political Economics 41 (4): 629-649.

Andrade, Rogério and Daniela M. Prates. 2013. 'Exchange rate dynamics in a peripheral monetary economy', Journal of Post Keynesian Economics 35(3): 399-416.

Andrews, D M. 1994. 'Capital Mobility and State Autonomy: Toward a Structural Theory of International Monetary Relations.' International Studies Quarterly 38 (2): 193-218.

Armijo, L. 1993. 'Brazilian Politics and Patterns of Regulation, 1945-1991.' In S Haggard, C H Lee and S Maxfield (eds), The Politics of Finance in Developing Countries. Ithaca and London: Cornell University Press, pp. 259-290.

Armijo, L E and S N Katada. 2014. 'Theorizing the Financial Statecraft of Emerging Powers.' New Political Economy 20 (1): 42-62.

Baker, A. 2018. 'Macroprudential regimes and the politics of social purpose.' Review of International Political Economy 25 (3): 293-316.

Batista, P N Jr. 1987. 'International Financial Flows to Brazil since the late 1960s: An Analysis of Debt Expansion and Payments Problems.' World Bank Discussion Papers 7.

Ban, C. 2016. Ruling Ideas: How Global Neoliberalism Goes Local. New York: Oxford University Press. Block, F L. 1980. Las Orígenes del Desorden Económico Internacional. Ciudad de Mexico: Fondo de Cultura.

Blyth, M. 2002. Great Transformations: Economic Ideas and Institutional Change in the Twentieth Century. New York: Cambridge University Press.

Bohle, D and B Greskovits. 2012. Capitalist Diversity on Europe's Periphery. Ithaca: Cornell University Press.

2019. 'Politicising embedded neoliberalism: continuity and change in Hungary's development model.' West European Politics 42 (5): 1069-1093.

Cerny, P G. 2008. 'Embedding Neoliberalism: The Evolution of a Hegemonic Paradigm.' Journal of International Trade and Diplomacy 2 (1): 1-46.

Chicago Board Options Exchange. n.d. 'VIX Index.' At https://markets.cboe.com/tradeable_products/vix/ [Accessed on 11 November 2020].

Chwieroth, J M. 2010. 'How do crises lead to change? Liberalizing Capital Controls in the early years of new order Indonesia.' World Politics 62 (3): 496-527.

2014. 'Controlling Capital: The International Monetary Fund and Transformative Incremental Change from Within International Organisations.' New Political Economy 19 (3): 445-469.

Cohen, B J. 2014. 'Will History Repeat Itself? Lessons for the Yuan.' In C Eichengreen and K Masashiro (eds), Renminbi Internationalization: Achievements, Prospects, and Challenges. Washington, DC: Brookings Institution Press, pp. 27-52.

2015. Currency Power: understanding monetary rivalry. Princeton: Princeton University Press. 
2018. Currency Statecraft: Monetary Rivalry and Geopolitical Ambition. Chicago: University of Chicago Press.

Dagher, J. 2018 'Regulatory Cycles: Revisiting the Political Economy of Financial Crises.' IMF Working Paper WP/18/8.

Das, S. 2019. 'China’s Evolving Exchange Rate Regime’, IMF Working Paper WP/19/50.

Davidson, P. 2017. Who's Afraid of John Maynard Keynes? Challenging Economic Governance in an Age of Growing Inequality. London: Palgrave Macmillan.

Eichengreen, B. 2019. Globalizing Capital. A History of the International Monetary System. $3^{\text {rd }}$ ed. Princeton: Princeton University Press.

Eichengreen, B, A Mehl and L Chitu. 2019. How Global Currencies Work: Past, Present, and Future. Princeton: Princeton University Press.

Epstein, G A. 2005. 'Introduction: Financialization and the World Economy'. In G A Epstein (ed), Financialization and the World Economy. Cheltenham: Edward Elgar Publishing, pp. 3-16.

Evans, P B. 1971. 'National autonomy and economic development: critical perspectives on multinational corporations in poor countries.' International Organization 25 (3): 675-692.

Fernández, A, M W Klein, A Rebucci, M Schindler and M Uribe. 2016. 'Capital Control Measures: A New Dataset.' IMF Economic Review 64: 548-574.

Fischer, S. 1998. 'Capital account liberalization and the role of IMF.' In S Fisher, R N Cooper, R Dornbusch, P M Garber, C Massad, J J Polak, D Rodrik and S S Tarapore (eds) Should the IMF pursue capital-account convertibility? Essays in International Finance 207. Princeton: International Finance Section, Department of Economics, Princeton University, pp. 1-10.

Fritz, B and D M Prates. 2018. 'Capital account regulation as part of the macroeconomic regime: comparing Brazil in the 1990s and 2000s.' European Journal of Economics and Economic Policies: Intervention 15 (3): 313-334.

Furtado, C. 1974. O mito do desenvolvimento econômico. $4^{\text {th }}$ ed. Rio de Janeiro: Paz e Terra.

Gallagher, K P. 2014. Ruling Capital: emerging markets and the re-regulation of cross border finance. Ithaca: Cornell University Press.

. 2015. 'Countervailing monetary power: Re-regulating capital flows in Brazil and South

Korea.' Review of International Political Economy 22 (1): 77-102.

Gallagher, K P, J A Ocampo, M Zhang and Y Yongding. 2014. 'Capital Account Liberalization in China: A Cautionary Tale.' GEGI Exchange, Global Economic Governance Initiative Policy Brief 2 (1): 1-6.

Ghosh, A R, J D Ostry and M S Qureshi. 2018. Taming the Tide of Capital Flows: a policy guide. Cambridge: The MIT Press.

Goldfajn, I and A Minella. 2007. 'Capital Flows and Controls in Brazil: What Have We learned?' In Sebastian Edwards (ed), Capital Controls and Capital Flows in Emerging Economies: Policies, Practices, and Consequences. Chicago: University of Chicago Press, pp. 349-419.

Gourinchas, P O, H Rey and M Sauzet. 2019. 'The International Monetary and Financial System.' Annual Review of Economics 11 (1): 859-893.

Grabel, I. 2017. When Things Don't Fall Apart: Global Financial Governance and Developmental Finance in an Age of Productive Incoherence. Cambridge: MIT Press. 
Helleiner, E. 1995. 'Explaining the Globalization of Financial Markets: Bringing States Back In.' Review of International Political Economy 2 (2): 315-341.

2010. 'A Bretton Woods Moment? The 2007-2008 crisis and the future of global finance.' International Affairs 86 (3): 619-636.

2019. 'The life and times of embedded liberalism: legacies and innovations since Bretton Woods.' Review of International Political Economy 26 (6): 1112-1135.

Helleiner, E and H Wang. 2019. 'The Richness of Financial Nationalism: The Case of China.' Pacific Affairs 92 (2): 211-234.

Ilzetzki, E, C M Reinhart and K S Rogoff. 2017. 'Exchange Arrangements Entering the 21st Century: Which Anchor Will Hold?' NBER Working Paper 23134.

International Monetary Fund (IMF). 2011. Recent Experiences in Managing Capital Inflows: CrossCutting Themes and Possible Policy Framework. Washington, DC: IMF.

2012. The Liberalization and Management of Capital Flows: An Institutional View. Washington, DC: IMF.

2016. Capital Flows - Review of Experience with the Institutional View. Washington, DC: IMF.

Jeanne, O, A Subramanian and J Williamson. 2012. Who Needs to Open the Capital Account? Washington, DC: Peterson Institute for International Economics.

Kaltenbruuner, A. 2018. 'Financialised internationalisation and structural hierarchies: a mixed-method study of exchange rate determination in emerging economies.' Cambridge Journal of Economics 42: 1315-1341.

Kaltenbrunner, A and J P Painceira. 2015. 'Developing Countries' changing Nature of Financial Integration and New Forms of External Vulnerability: The Brazilian Experience.' Cambridge Journal of Economics 39: 1281-1306.

2018. 'Subordinated Financial Integration and Financialisation in Emerging Capitalist Economies: The Brazilian Experience.' New Political Economy 23 (3): 290-313.

Keynes, J M. 1924. A Tract on Monetary Reform. London: Macmillan.

1930. A Treatise on Money. London: Macmillan.

Kirshner, J. 2003. 'The Inescapable Politics of Money.' In J Kirshner (ed), Monetary Orders: Ambiguous Economics, Ubiquitous Politics. Ithaca: Cornell University Press, pp. 3-24.

2009. 'Realist political economy: Traditional themes and contemporary challenges.' In

M Blyth (ed), Routledge Handbook of International Political Economy (IPE): IPE as a Global Conversation. London and New York: Routledge, pp. 46-57.

Korinek, A. 2018. 'Regulating capital flows to emerging markets: An externality view.' Journal of International Economics 111: 61-80.

Kregel, J. 2004. 'External Financing for Development and International Financial Instability.' UNCTAD G-24 Discussion Paper Series.

Lane, P R and G M Milesi-Ferretti. 2018. 'The External Wealth of Nations Revisited: International Financial Integration in the Aftermath of the Global Financial Crisis.' IMF Economic Review 66: 189-222.

Levitt, K P. 2006. 'Keynes and Polanyi: the 1920s and the 1990s.' Review of International Political Economy 13 (1): 152-177. 
Loureiro, F P. 2014. 'The Alliance For or Against Progress? US-Brazilian Financial Relations in the Early 1960s.' Journal of Latin American Studies 46 (2): 323-351.

Minsky, H P. 1993. 'Financial Integration and National Economic Policy'. Hyman P. Minsky Archive 41. Moschella, M. 2012. 'Seeing Like the IMF on Capital Account Liberalisation.' New Political Economy 17 (1): 59-76.

Obstfeld, M. 2015. 'Trilemmas and trade-offs: living with financial Globalization.' BIS Working Papers 480: 1-63.

Ocampo, J A. 2001. 'International Asymmetries and the Design of the International Financial System.' Serie Temas de Conyuntura 15.

2017. Resetting the International Monetary (Non)System. Oxford: Oxford University Press.

Ostry, J D, A R Ghosh and A Korinek. 2012. 'Multilateral aspects of managing the capital account.' IMF Staff Discussion Note SDN/12/10: 1-24.

Paula, L F de, B Fritz and D M Prates. 2017. 'Keynes at the periphery: Currency hierarchy and challenges for economic policy in emerging economies.' Journal of Post Keynesian Economics 40 (2): 183-202.

Polanyi, K. 2001. The Great Transformation: The Political and Economic Origins of Our Time. Boston: Beacon Press.

Prasad, E. 2016. Gaining Currency: The Rise of the Renminbi. Oxford: Oxford University Press.

Prasad, E, K Rogoff, S J Wei and M A Kose. 2003. Effects of Financial Globalization on Developing Countries: Some Empirical Evidence. Washington, DC: IMF.

Prasad, E and S J Wei. 2007. 'The Chinese Approach to Capital Inflows: Patterns and Possible Explanations.' In S Edwards (ed), Capital Controls and Capital Flows in Emerging Economies: Policies, Practices, and Consequences. Chicago: University of Chicago Press, pp. 421-480.

Prates, D M and L F de Paula. 2017. 'Capital account regulation in Brazil: An assessment of the 20092013 period.' Brazilian Journal of Political Economy 37 (1): 108-129.

Prebisch, R. 1949. The Economic Development of Latin America and Its Principal Problems. New York: United Nations Department of Economic Affairs.

Rey, H. 2015. 'Dilemma not Trilemma: The global financial cycle and monetary policy independence.' NBER Working Paper 21162.

Ruggie, J G. 1982. 'International Regimes, Transactions, and Change: Embedded Liberalism in the Postwar Economic Order' International Organization 36 (2): 379-415.

Sandbrook, R. 2011. 'Polanyi and Post-neoliberalism in the Global South: Dilemmas of Reembedding the Economy'. New Political Economy 16 (4): 415-443.

Skidelsky, R. 2009. Keynes: The Return of the Master. New York: PublicAffairs.

Souza, F E P and F J C de Carvalho. 2011. 'Exchange rate regulation, the behaviour of exchange rates, and macroeconomic stability in Brazil.' Revista de Economia Política 31 (4): 563-578.

Stiglitz, J E. 2019. 'Ten Years Later' In S O'Halloran and T Groll (eds), After the Crash: Financial Crisis and Regulatory Responses. New York: Columbia University Press.

Strange, S. 1998. Mad money: when markets outgrow governments. Ann Arbor: University of Michigan Press. 
The World Bank. n.d. 'DataBank | The World Bank.' At https://databank.worldbank.org/home.aspx [Accessed on 11 November 2020].

Tobin, J. 2000. 'Financial Globalization.' World Development 28 (6): 1101-1104.

Vermeiren, M and S Dierckx. 2012. 'Challenging Global Neoliberalism? The global political economy of China's capital controls.' Third World Quarterly 33 (9): 1647-1668.

Yongding, Y. 2009. 'The Management of Cross-Border Capital Flows and Macroeconomic Stability in China.' TWN Global Economy Series 14.

\section{About the authors}

Luiza Peruffo is an Assistant Professor in the Department of Economics and International Relations and a Collaborator Professor in the Post-Graduate Programme in International Strategic Studies at the Federal University of Rio Grande do Sul (UFRGS) in Brazil. She holds a Ph.D. in Politics and International Studies from the University of Cambridge and a M.A. in Development Economics from UFRGS. Her main research interests are focused on the area of international political economy, especially on the international monetary and financial system and the challenges faced by emerging economies. She leads a research project in this area at the NEBRICS (Centre for BRICS studies at UFRGS). Dr. Peruffo worked as Senior Economics and Trade Officer at the British Embassy in Brasília from 2016 to 2018.

Pedro Perfeito da Silva is a Ph.D. candidate in the Department of Political Science at the Central European University (CEU) and a Junior Visiting Fellow at the Institute for Human Sciences (IWM) in Austria. He holds a M.A. in Economics from the Federal University of Rio Grande do Sul (UFRGS). His main research interests are focused on political economy and macroeconomics, especially on the politics of capital flows management, and on monetary policy and State-owned credit supply to explain the challenges faced by emerging and developing countries. Pedro worked as a temporary instructor at UFRGS and was a visiting researcher at the Hertie School of Governance (Germany) and the Tallinn University of Technology (Estonia).

André Moreira Cunha is a Full Professor in the Department of Economics and International Relations at the Federal University of Rio Grande do Sul (UFRGS) and a researcher at the National Council for Technological and Scientific Development (CNPq) in Brazil. He holds a Ph.D. in Economics from the University of Campinas (Unicamp) in Brazil. His research focuses on the macroeconomic aspects of international trade and finance; the impacts of globalization on Latin American countries, particularly Brazil; the economic development of emerging countries; and on the economics of culture and creativity. Dr. Cunha worked as economic advisor to the Far South Development Bank (BRDE) Board of Directors and was a visiting scholar at the University of Cambridge (United Kingdom), at Leiden University (Netherlands), at Fundación Ortega y Gasset (Spain), among other institutions. 


\section{Regulação da Conta Capital e Autonomia Nacional: A Economia Política da Nova Economia do Bem-Estar}

Resumo: A crise financeira global (GFC) de 2007-2009 corroeu o consenso em torno dos benefícios da mobilidade de capital no escopo da economia tradicional. Neste contexto, este artigo discute até que ponto a nova posição dominante em medidas de gestão de fluxo de capital, com base na Nova Economia do Bem-Estar, expande o espaço político das economias em desenvolvimento e emergentes (EDEs). Este artigo argumenta que a nova posição pode ser classificada como neoliberal enraizada, uma vez que mantém a liberalização como objetivo final, embora aceite mitigar algumas de suas consequências nefastas. Após comparar as políticas da conta capital do Brasil e da China, o artigo conclui que as prescrições de política da Nova Economia do Bem-Estar não levam a níveis mais elevados de autonomia nacional para as EDEs, sendo também incapazes de conter a instabilidade financeira nesses países.

Palavras-chave: mobilidade de capital; controles de capital; Nova Economia do Bem-Estar; Economia Política; neoliberalismo enraizado.

Received on 2 April 2020, and approved for publication on 8 October 2020.

\section{(c)) BY-NC} https://creativecommons.org/licenses/by-nc/4.0/ 